\title{
Anthelmintic effect of Cymbopogon citratus essential oil and its nanoemulsion on sheep gastrointestinal nematodes
}

\author{
Efeito anti-helmíntico do óleo essencial de Cymbopogon citratus e sua nanoemulsão sobre \\ nematoides gastrintestinais de ovinos
}

\author{
Iara Tersia Freitas Macedo ${ }^{1}$; Lorena Mayana Beserra de Oliveira ${ }^{1}$; Weibson Paz Pinheiro André ${ }^{1}$; \\ José Vilemar de Araújo Filho ${ }^{1}$; Jéssica Maria Leite dos Santos ${ }^{1,2}$; Fernanda Cristina Macedo Rondon ${ }^{1}$; \\ Wesley Lyeverton Correia Ribeiro ${ }^{1,3}$; Ana Lourdes Fernandes Camurça-Vasconcelos ${ }^{1,4}$; Erick Falcão de Oliveira ${ }^{5}$; \\ Haroldo César Beserra de Paula ${ }^{5}$ C Claudia Maria Leal Bevilaqua ${ }^{1 *}$ (i)
}

\author{
${ }^{1}$ Programa de Pós-graduaçăo em Ciências Veterinárias, Laboratório de Doenças Parasitárias, Faculdade de Veterinária, Universidade \\ Estadual do Ceará - UECE, Fortaleza, CE, Brasil \\ ${ }^{2}$ Centro Universitário - INTA-Uninta, Sobral, CE, Brasil \\ ${ }^{3}$ Departamento de Fisiologia e Farmacologia, Faculdade de Medicina, Universidade Federal do Ceará - UFC, Fortaleza, CE, Brasil \\ ${ }^{4}$ Faculdade Terra Nordeste - FATENE, Fortaleza, CE, Brasil \\ ${ }_{5}^{5}$ Departamento de Química Analítica e Físico-Química, Laboratório de Biopolímeros, Universidade Federal do Ceará - UFC, \\ Fortaleza, CE, Brasil
}

Received January 22, 2019

Accepted May 24, 2019

\begin{abstract}
The anthelmintic resistance stimulated the search for strategies for controlling gastrointestinal nematodes, including the use of free essential oils or its nanoemulsion. This study evaluated the anthelmintic efficacy of Cymbopogon citratus essential oil (CcEO) and C. citratus essential oil nanoemulsion (CcEOn). Pysicochemical analyses were performed. The in vitro effect was determined using the egg hatch test (EHT) on Haemonchus contortus and in vivo effect was evaluated in sheep infected with gastrointestinal nematodes. The animals were treated with $\mathrm{CcEO}(500 \mathrm{mg} / \mathrm{kg})$ or CcEOn $(450 \mathrm{mg} / \mathrm{kg})$ for the fecal egg count (FEC) and the determination of worm burden. The main component of CcEO was citral. The CcEO content in the nanoemulsion was $20 \%(\mathrm{v} / \mathrm{v})$, and the mean particle size was $248 \mathrm{~nm}$. In EHT, CcEO and CcEOn $(1.25 \mathrm{mg} / \mathrm{mL})$ inhibited larval hatching by 98.4 and $97.1 \%$, respectively. Three animals treated with CcEO died whereas in the group treated with CcEOn one animal died. The FEC and total worm burden of the treated groups did not differ from the negative control $(\mathrm{p}>0.05)$. The CcEOn showed efficacy only on $H$. contortus $(\mathrm{p}<0.05)$. In conclusion, nanoencapsulation reduced toxicity and increased efficacy on $H$. contortus.
\end{abstract}

Keywords: Phytotherapy, nanotechnology, Haemonchus contortus, small ruminants.

\section{Resumo}

A resistência anti-helmíntica estimulou a busca por estratégias de controle de nematoides gastrintestinais, incluindo óleos essenciais livres ou em nanoemulsão. Este estudo avaliou a eficácia anti-helmíntica do óleo essencial de Cymbopogon citratus (OECc) e da nanoemulsão do óleo essencial de C. citratus (nOECc). Análises físico-químicas foram realizadas. O efeito in vitro foi determinado no teste de eclosão de ovos (TEO) sobre Haemonchus contortus e o efeito in vivo foi avaliado em ovinos infectados com nematoides gastrintestinais. Os animais foram tratados com OECc $(500 \mathrm{mg} / \mathrm{kg})$ ou nOECc $(450 \mathrm{mg} / \mathrm{kg})$ para determinação do número de ovos por grama de fezes (OPG) e carga parasitária. O principal constituinte do OECc foi citral. O conteúdo de OECc na nanoemulsão foi $20 \%$ e o tamanho médio de partícula foi 248 nm. No TEO, OECc e nOECc $(1,25 \mathrm{mg} / \mathrm{mL})$ inibiram 98,4 e 97,1\% da eclosão larvar, respectivamente. Três animais tratados com o OECc morreram, enquanto um animal do grupo tratado com a nOECc morreu. O OPG e a carga parasitária total dos grupos tratados não diferiram do controle negativo ( $\mathrm{p}>0.05)$. A nOECc apresentou eficácia somente sobre $H$. contortus $(\mathrm{p}<0.05)$. Como conclusão, o nanoencapsulamento reduziu a toxicidade e aumentou a eficácia sobre $H$. contortus.

Palavras-chave: Fitoterapia, nanotecnologia, Haemonchus contortus, pequenos ruminantes.

\footnotetext{
*Corresponding author: Claudia Maria Leal Bevilaqua. Programa de

Pós-graduaçâo em Ciências Veterinárias, Laboratório de Doenças Parasitárias,

Faculdade de Veterinária, Universidade Estadual do Ceará - UECE, Av. Dr.

Silas Munguba, 1700, Campus do Itaperi, CEP 60714-903, Fortaleza, CE,

Brasil. e-mail: claudiamlb@yahoo.com.br.
} 


\section{Introduction}

Gastrointestinal nematode is one of the factors that reduce productivity of livestock worldwide (ROEBER et al., 2017). Control measures for parasitic diseases of livestock have relied heavily on the use of commercial anthelmintics. However, the injudicious use of these drugs resulted in nematode resistance to anthelmintics in different parts of the world (KOTZE \& PRICHARD, 2016). The intensification of animal production has led to an increasing demand for more effective and low cost anthelmintics (ADEMOLA et al., 2004). These concerns have stimulated the search for alternative control methods, such as the use of medicinal plants (RIBEIRO et al., 2015).

Cymbopogon citratus is a tropical plant that belongs to the Poaceae (Gramineae) family. An ethnoveterinary study carried out on the Colares island, Pará state, eastern Amazon, Brazil, reported that $C$. citratus has anthelmintic indication (RITTER et al., 2012). Several studies have showed that the $C$. citratus essential oil (CcEO) has a number of biological properties including activity against Haemonchus contortus in Meriones unguiculatus (MACEDO et al., 2015). Nevertheless, the anthelmintic activity of CcEO has not yet been assessed in small ruminants.

Essential oils are complex mixtures of active substances of plant origin which exhibit a variety of properties. However there are some limitations related to the stability of these active substances that hinder their preservation. These substances may change rapidly due volatilization and oxidation of their chemical constituents (GONSALVES et al., 2009). In order to overcome these drawbacks, carrier systems are used which increase the stability of these compounds and modulate substance release (TIWARI et al., 2010). Chitosan is a non-toxic polymer that may be used as an encapsulating agent as it has biocompatible, biodegradable properties and is also capable of forming films, gels, beads, and particles (WORANUCH \& YOKSAN, 2013). To protect and maximize the nematicidal effect of oils, encapsulation techniques employing chitosan have been investigated (RIBEIRO et al., 2013, 2015).

The objective of this study was to evaluate the anthelmintic activity of CcEO and C. citratus essential oil nanoemulsion (CcEOn) using chitosan by egg hatching test and on sheep naturally infected with gastrointestinal nematodes.

\section{Materials and Methods}

\section{Chemical analysis of Cymbopogon citratus essential oil}

A commercial form of CcEO preparated by the company Phytoterápica (State of São Paulo, Brazil, lot 185) was used. The chemical composition of the CcEO used in this study was determined by gas chromatography and mass spectrometry (ADAMS, 2001).

\section{Nanoemulsion of Cymbopogon citratus essential oil and physicochemical characterization}

Chitosan powder $\left(\right.$ Polymar $\left.^{\circledR}\right)$ was used as encapsulant biopolymer. To promote encapsulation, a mixture of CcEO and tween 80 at the ratio of $2: 1$ was added to a solution of $1 \%$ chitosan $(\mathrm{v} / \mathrm{v})$ under stirring at $188.5 \mathrm{rad} / \mathrm{s}$ for $5 \mathrm{~min}$ in a mechanical stirrer. The resulting emulsion was evaluated according to the macroscopic characteristics of CcEOn stability which were observed over $72 \mathrm{~h}$ at $27^{\circ} \mathrm{C}$. The size and distribution of nanoparticles in solution were determined using a beam of red light (ZetaSizer 3600, Malvern, United Kingdom).

\section{Animal welfare}

The protocol was approved by the ethics committee for animal use of Universidade Estadual do Ceará (number 09657334-1).

\section{Egg hatch test}

The egg hatch test (EHT) was performed according to the method described by Coles et al. (1992). For this, sheep experimentally infected with $H$. contortus was used as a source of fresh eggs, which were recovered according to Hubert \& Kerboeuf (1992). An suspension $(250 \mu \mathrm{L})$ containing approximately 100 fresh eggs was incubated with $250 \mu \mathrm{L}$ of essential oil or nanoemulsion at the concentrations of $0.07,0.15,0.31,0.62$, and $1.25 \mathrm{mg} / \mathrm{mL}$ for $48 \mathrm{~h}$ at $27^{\circ} \mathrm{C}$. The $\mathrm{CcEOn}$ concentrations were adjusted according to the volume of essential oil present in the nanoemulsion. After this time, drops of Lugol's iodine solution were added. The eggs and first-stage larvae (L1) were counted under a light microscope. This test had two controls: a negative and a positive. The negative control containing $3 \%$ tween 80 and $1 \%$ chitosan. The tween 80 concentration was the same used to dilute the oil and its nanuelmusion. The positive control containing $0.025 \mathrm{mg} / \mathrm{mL}$ thiabendazole. Two repetitions with five replicates for each concentration and for each control were performed.

\section{In vivo test}

Thirty sheep of both sexes between the ages of 10 to 16 months with an average weight of $22 \mathrm{~kg}$ were kept in paddocks and fed with fresh grass, salt-mineral supplement, and water ad libitum. Individual fecal samples were collected to determine the level of natural infection by gastrointestinal nematode using a modified McMaster technique (UENO \& GONÇALVES, 1998). Sheep were divided into three homogeneous groups according to the fecal egg count $($ FEC). Each group $(n=10)$ received orally the following treatments for three days: G1 $-500 \mathrm{mg} / \mathrm{kg}$ CcEO; G2 - $450 \mathrm{mg} / \mathrm{kg}$ CcEOn; and G3 (control) - 3\% tween 80 and $1 \%$ chitosan. The CcEOn dose was adjusted according to the volume of essential oil present in the nanoemulsion. The animals of G2 received the smallest dose because the nanoencapsulation may potentiate the anthelmintic effect of CcEO. For the fecal egg count reduction test (FECRT), samples from each animal were collected before and after 7 and 14 days of treatment to determine the FEC using the McMaster technique (UENO \& GONÇALVES, 1998) and to perform fecal cultures according to Roberts \& O'Sullivan (1950).

The controlled test was performed 15 days after treatment when five sheep of each group (G1, G2 and G3) were euthanized for parasite count and estimate parasite load. The selection of 
animals for euthanasian was aleatory. The gastrointestinal tract of each necropsied animal was removed after applying double ligatures at the abomasum, small intestine, and large intestines, and were then examined separately. Each of these segments of the gastrointestinal tract was opened and their contents thoroughly washed separately (WOOD et al., 1995). A sample (5\%) of the contents from each of these parts of the gastrointestinal tract was collected individually for parasitological analysis. Samples were stored in AFA solution (alcohol, formol, acetic acid, and water). Worms recovered from the gastrointestinal contents were identified using a stereomicroscope (UENO \& GONÇALVES, 1998).

\section{Statistical Analysis}

The efficacy of each treatment in EHT was determined based on the following formula:

$$
\mathrm{EHT}=\frac{\text { number of eggs }}{\text { number of hatched larvae }+ \text { number of eggs }} \times 100
$$

To evaluate the difference between the concentrations of a single product, data were analyzed using the one-way analysis of variance (ANOVA), and were compared using the Tukey's test $(\mathrm{p}<0.05)$. To compare the results of the same concentration of $\mathrm{CcEO}$ and $\mathrm{CcEO}$ was used the two-way ANOVA followed by the Bonferroni's test $(\mathrm{p}<0.05)$. The effective concentration to inhibit $50 \%\left(\mathrm{EC}_{50}\right)$ of larvae hatching was determined by linear regression (ANDRÉ et al., 2017).

The anthelmintic efficacy of $\mathrm{CcOE}$ and $\mathrm{CcOEn}$ was interpreted through the FECRT based on each group arithmetic mean FEC using the following formula:

$$
\text { FECRT }=100 \times\left(1-\frac{\mathrm{T} 2}{\mathrm{~T} 1} \times \frac{\mathrm{C} 1}{\mathrm{C} 2}\right)
$$

In this formula, the arithmetic FEC means in controls $(\mathrm{C})$ and treated (T) animals before (T1 and $\mathrm{C} 1$ ) and 7 or 14 days after (T2 and C2) deworming were compared (DASH et al., 1988), using BootStreat 1.0 software (CABARET, 2014). This software was only used to calculate the anthelmintic efficacy of $\mathrm{CcOE}$ and CcOEn. The FEC data were log transformed $\left(\log _{10}[\mathrm{x}+1]\right)$, submitted to ANOVA and compared using Newman-Keuls's test. The significance level was $\mathrm{p}<0.05$.

In the controlled test, the percentage of reduction in parasitic burden in the treated sheep group was estimated using the following formula:

Controlled test $=\frac{\text { control group worm burden }- \text { treated group worm burden }}{\text { control group worm burden }} \times 100$

The worm burden data were $\log$ transformed $\left(\log _{10}[\mathrm{x}+1]\right)$, analyzed by ANOVA, and compared with the Newman-Keuls's test $(\mathrm{p}<0.05)$.

The ANOVA and Tukey, Bonferroni and Newman-Keuls's tests were realized using the GraphPad Prism ${ }^{\circledR} 5.0$ software (GraphPad Software Inc., EUA). The $\mathrm{EC}_{50}$ of larvae hatching was determined using IBM SPSS Statistic version 17 for Windows (IBM, USA).

\section{Results}

The main components of CcEO were 3,7-nonadien-2-one, 4,8-dimethyl (24.86\%), geranial (18.98\%), neral (17.77\%), nerol (9.31\%), 1-heptadec-1-ynyl-cyclopentanol (9.63\%), 7,7-dimethylbicycloheptan-2-ol (7.96\%) and d-limonene (2.44\%).

To obtain a stable nanoemulsion (no phase separation), 20.0\% $(\mathrm{v} / \mathrm{v})$ of the $\mathrm{CcEO}$ content was used. Analysis of the resulting nanoemulsion particles demonstrated a mean size of $248 \mathrm{~nm}$ with bimodal distribution. The nanoemulsion was white, with a milky consistency and could flow through an oral dosing pistol. No phase separation was visually observed after $72 \mathrm{~h}$.

The mean efficacy of $\mathrm{CcEO}$ and $\mathrm{CcEOn}$ obtained in the EHT is presented in Table 1. CcEO and $\mathrm{CcEOn}$ showed ovicidal activity at all tested concentrations, and for the higher concentration $(1.25 \mathrm{mg} / \mathrm{mL})$, the effect was similar to that of thiabendazole $(p>0.05)$. The data of Table 1 indicate that the $\mathrm{CcEO}$ and $\mathrm{CcEOn}$ had dose-dependent effect. The $\mathrm{EC}_{50}$ values in the EHT were 0.15 and $0.16 \mathrm{mg} / \mathrm{mL}$ for $\mathrm{CcEO}$ and $\mathrm{CcEOn}$, respectively.

Three animals treated with $\mathrm{CcEO}$ died whereas in the group treated with $\mathrm{CcEOn}$ one animal died. The FEC of sheep at 8 and 15 days post-treatment with $\mathrm{CcEO}$ and $\mathrm{CcEOn}$ is expressed in Table 2. Reduction in treated group with $\mathrm{CcEO}$ and $\mathrm{CcOEn}$ varied from 19.5 to $23.9 \%$ and 51.7 to $47.0 \%$, respectively. Although the numerical results of mean FEC were different, there was no significant difference between the treated groups and the control group ( $>0.05)$. The most prevalent nematode genus in fecal cultures was Haemonchus followed by Trichostrongylus (Table 2).

The mean efficacy of $\mathrm{CcEO}$ and $\mathrm{CcEOn}$ on sheep worm burden is summarized in Table 3. The species found were H. contortus, Trichostrongylus colubriformis, Oesophagostomum columbianum and Trichuris ovis. However, due to the small number of parasites found, the worm burden of the large intestine was not statistically analyzed. The total worm burden of the groups treated with $\mathrm{CcEO}$ and $\mathrm{CcEOn}$ and control group was similar $(\mathrm{p}>0.05)$. $\mathrm{CcEO}$ and $\mathrm{CcEOn}$ were more effective against $H$. contortus because reductions in adult worm burden were 66.4 and $83.1 \%$, respectively. $H$. contortus adult worm burden of sheep treated with CcEOn was different in the treated group with $\mathrm{CcEO}$ and the control group $(\mathrm{p}<0.05)$. The effect on T. colubriformis was not statistically different between treated and control groups $(\mathrm{p}>0.05)$.

Table 1. Efficacy percentage (mean \pm standard deviation) of Cymbopogon citratus essential oil (CcEO) and $C$. citratus essential oil nanoemulsion (CcEOn) on egg hatching of Haemonchus contortus.

\begin{tabular}{ccc}
\hline Concentrations $(\mathbf{m g} / \mathbf{m L})$ & CcEO & CcEOn \\
\hline 1.25 & $98.4 \pm 2.4^{\mathrm{Aa}}$ & $97.1 \pm 4.7^{\mathrm{Aa}}$ \\
0.62 & $96.0 \pm 2.8^{\mathrm{Ab}}$ & $73.2 \pm 10.1^{\mathrm{Ba}}$ \\
0.31 & $74.8 \pm 14.9^{\mathrm{Bb}}$ & $58.1 \pm 9.4^{\mathrm{Ca}}$ \\
0.15 & $37.1 \pm 7.2^{\mathrm{Ca}}$ & $49.4 \pm 7.1^{\mathrm{Ca}}$ \\
0.07 & $27.5 \pm 8.0^{\mathrm{Ca}}$ & $34.9 \pm 16.3^{\mathrm{Da}}$ \\
Negative control & $9.8 \pm 6.0^{\mathrm{Da}}$ & $9.8 \pm 6.0^{\mathrm{Ea}}$ \\
Positive control & $97.1 \pm 1.6^{\mathrm{Aa}}$ & $97.1 \pm 1.6^{\mathrm{Aa}}$ \\
\hline
\end{tabular}

Capital letters compare mean in the columns and lowercase letters compare mean in the rows. Different letters indicate significantly different values $(\mathrm{p}<0.05)$. 
Table 2. Fecal egg count (mean FEC \pm standard deviation) and gastrointestinal nematode larvae (\%) in coprocultures of sheep before and after treatment with Cymbopogon citratus essential oil (CcEO) and C. citratus essential oil nanoemulsion (CcEOn).

\begin{tabular}{|c|c|c|c|}
\hline Treatment & Day 0 & Day 8 & Day 15 \\
\hline \multicolumn{4}{|l|}{ CcEO $(500 \mathrm{mg} / \mathrm{kg})$} \\
\hline Mean FEC & $3,720 \pm 1,941.4^{\mathrm{Aa}}$ & $1,900 \pm 2,002^{\mathrm{Aa}}$ & $1,729 \pm 2,072^{\mathrm{Aa}}$ \\
\hline Efficacy $(\%)$ & - & 19.6 & 23.9 \\
\hline Haemonchus spp. & 81 & - & 77 \\
\hline Trichostrongylus spp. & 15 & - & 20 \\
\hline Oesophagostomum spp. & 4 & - & 3 \\
\hline \multicolumn{4}{|l|}{ CcEOn $(450$ mg/kg) } \\
\hline Mean FEC & $3,969 \pm 2,083^{\mathrm{Aa}}$ & $1,219 \pm 877.1^{\mathrm{Ab}}$ & $1,288 \pm 972.4^{\mathrm{Ab}}$ \\
\hline Efficacy $(\%)$ & - & 51.7 & 47.0 \\
\hline Haemonchus spp. & 80 & - & 64 \\
\hline Trichostrongylus spp. & 19 & - & 27 \\
\hline Oesophagostomum spp. & 1 & - & 9 \\
\hline \multicolumn{4}{|l|}{ Negative control } \\
\hline Mean FEC & $3,381 \pm 1,623^{\mathrm{Aa}}$ & $2,150 \pm 1,230^{\mathrm{Aa}}$ & $2,069 \pm 831.5^{\mathrm{Aa}}$ \\
\hline Haemonchus spp. & 70 & - & 68 \\
\hline Trichostrongylus spp. & 28 & - & 26 \\
\hline Oesophagostomum spp. & 2 & - & 6 \\
\hline
\end{tabular}

Capital letters compare mean in the columns and lowercase letters compare mean in the rows. Different letters indicate significantly different values ( $\mathrm{p}<0.05$ ).

Table 3. Worm burden (mean \pm standard deviation) of sheep after treatment with Cymbopogon citratus essential oil (CcEO) and C. citratus essential oil nanoemulsion (CcEOn).

\begin{tabular}{lccc}
\hline \multicolumn{1}{c}{ Treatment } & Haemonchus contortus & Trichostrongylus colubriformis & Total \\
\hline CcEO $(500 \mathrm{mg} / \mathrm{kg})$ & & & $844 \pm 752.6^{\mathrm{A}}$ \\
Mean worm burden & $200 \pm 156.8^{\mathrm{A}}$ & 38.4 & $1,044 \pm 788.2^{\mathrm{A}}$ \\
Efficacy $(\%)$ & 66.4 & $988 \pm 842.1^{\mathrm{A}}$ & 46.9 \\
CcEOn $(450 \mathrm{mg} / \mathrm{kg})$ & & 27.9 & $1,088 \pm 837^{\mathrm{A}}$ \\
Mean worm burden & $100 \pm 52.9^{\mathrm{B}}$ & & 44.7 \\
Efficacy $(\%)$ & 83.1 & $1,372 \pm 721.6^{\mathrm{A}}$ & $1,968 \pm 422^{\mathrm{A}}$ \\
Negative control & & & \\
Mean worm burden & $596 \pm 657.1^{\mathrm{A}}$ & & \\
\hline
\end{tabular}

Different letters indicate significantly different values $(\mathrm{p}<0.05)$.

\section{Discussion}

The use of medicinal plants with anthelmintic activity has been regarded as an efficient control measure against gastrointestinal parasitism (ANDRÉ et al., 2018). Essential oils from plants consist of an important group of substances that may be used as an alternative or adjunct antiparasitic therapy (ANTHONY et al., 2005). These oils interfere with helminth metabolism by inhibiting or disorganizing vital functions of the nematode from its early stages of development onwards, and can also induce nervous system derangement of nematodes inhibiting the motility of these worms (OKA et al., 2000; ANDRÉ et al., 2017).

The anthelmintic properties of $\mathrm{CcEO}$ are mainly attributed to its major component which is citral. Citral is a natural combination of two isomeric aldehydes, neral (cis-citral) and geranial (trans-citral), that together correspond to approximately $65-85 \%$ of the total oil composition of $C$. citratus (SADDIQ \& KHAYYAT, 2010). In the present study, citral concentration was $36.75 \%$. In another study, $\mathrm{CcEO}$ consisted of $97.7 \%$ of citral and was able to reduce $38.6 \%$ of the parasite load of $M$. unguiculatus experimentally infected with H. contortus (MACEDO et al., 2015). Studies have demonstrated that citral is capable of combating several nematodes including Anisakis simplex, Bursaphelenchus xylophilus and Meloidogyne incognita (BAUSKE et al., 1994; HIERRO et al., 2006; CHOI et al., 2007). Many factors including genetic variation, plant ecotype or variety, plant nutrition, application of fertilizers, geographic location of the plants, surrounding climate, seasonal variations, stress during growth or maturity and also the post harvest drying and storage, affect the chemistry of essential oils. In addition, type of plant material used and the method of extraction determine the yield and composition (constituents) of an essential oil, and thereby decides its characteristic biological properties (RAUT \& KARUPPAYIL, 2014). Besides the lower concentration of citral in the essential oil used in our study, other factors such as synergistic interactions among essential oil constituents may have affected the anthelmintic activity.

In the present study, $\mathrm{CcEO}$ and $\mathrm{CcEOn}$ presented a statistically similar efficacy in the EHT. Previous studies have demonstrated that the inhibition of larvae hatching by Eucalyptus citriodora and 
Eucalyptus staigeriana essential oils was enhanced by nanoencapsulation with chitosan 1\% (RIBEIRO et al., 2014, 2015). In these studies, the concentration of essential oils in nanoemulsions was $36.4 \%$. In the present experimental trial, the concentration of the essential oil of $C$. citratus in the nanoemulsion was $20 \%$. Possibly, the higher concentration of the encapsulating matrix in relation to the essential oil retained in the polymer system influenced the controlled release process in the aqueous environment of EHT. The diffusion of retained drugs in nanoemulsions occurs when water enters the polymer system resulting in swelling and subsequent release of the encapsulated drugs (DASH et al., 2011).

The essential oil of $E$. staigeriana $(500 \mathrm{mg} / \mathrm{kg})$ was able to reduce egg excretion in the feces of the goats in 76.5\% (MACEDO et al., 2010). In goats treated with the essential oil of E. citriodora $(500 \mathrm{mg} / \mathrm{kg})$, there was a decrease of $60.3 \%$ in the FEC (MACEDO et al., 2011). In sheep, the essential oil of $L$. sidoides $(283 \mathrm{mg} / \mathrm{kg}$ ) reduced the FEC in 54\% (CAMURÇA-VASCONCELOS et al., 2008). In the present study, on day 15 post-treatment, efficacy of $\mathrm{CcEO}$ $(500 \mathrm{mg} / \mathrm{kg})$ and CcEOn (450 mg/kg) on FEC was 23.9 and $47.0 \%$, respectively. However, the FEC in the control and treated groups did not differ significantly. Similar results were observed when the anthelmintic efficacy of the free and nanoencapsulated essential oil of $E$. citriodora $(250 \mathrm{mg} / \mathrm{kg}$ ) was evaluated (RIBEIRO et al., 2014). This fact can be explained by the high values of standard deviation found in mean FEC. Besides the egg fecal excretion is a variable measure which is influenced not only by worm burden (FORTES \& MOLENTO, 2013).

Haemonchus contortus is a blood-sucking abomasal nematode with high prevalence and intensity, and is considered the most pathogenic gastrointestinal helminth of small ruminants. In the presented study, CcEOn was able to significantly reduce the parasite load of $H$. contortus in the controlled test. However, the anthelmintic activity of CcEOn on T. colubriformis was lower in comparison with $H$. contortus. Similar results were obtained in studies conducted by Mesquita et al. (2013) using E. staigeriana essential oil nanoencapsulated ( $4 \%$ chitosan). There was a reduction of $83.7 \%$ on $H$. contortus parasite load while there was a decrease of $22.3 \%$ in the parasite burden of small intestine nematodes. These results can be explained by the bioadhesive properties of chitosan on the abomasal mucosa (SOSNIK et al., 2014). Benefits associated with the bioadhesive property of this polysaccharide include retention of the nanoemulsion in the gastrointestinal tract which improves drug absorption, increases drug bioavailability, and increases drug concentrations in tissues (HEJAZI \& AMIJI, 2003; RIBEIRO et al., 2015).

A previous study was performed to evaluate the toxicity of $\mathrm{CcEO}$ in rats, verifying that until the dose of $1.000 \mathrm{mg} / \mathrm{kg}$ presented no toxicity (FANDOHAN et al., 2008). In another study, the administration of $800 \mathrm{mg} / \mathrm{kg}$ of $\mathrm{CcEO}$ to $M$. unguiculatus also presented no toxicity (MACEDO et al., 2015). In the group treated with $\mathrm{CcEO}$, three animals died whereas in the group treated with $\mathrm{CcEOn}$ one animal died. The explanation for the toxicity found in present study can be associated to different chemical composition of the essential oil. However, before death, the sheep presented sialorrhea. The animals may have aspirated the $\mathrm{CcEO}$ or $\mathrm{CcEOn}$ and died due to wrong-route administration. Nevertheless, the death cause cannot be determined, since necropsy was not performed. In addition, the encapsulation technique used in the present experiment allowed the formation of nanoparticles of chitosan matrix that enhance the $\mathrm{CcEO}$ activity on $H$. contortus and decrease its toxicity in sheep. In mice, the nanoemulsion of the E. citriodora essential oil was less toxic to the experimental animals in comparison with free oil of this plant (RIBEIRO et al., 2014).

To our knowledge, this study is the first to assess the anthelmintic activity of $C$. citratus oil essential and its nanoemulsion in sheep. The results indicate that $C$. citratus may affect $H$. contortus and suggest potential use of $\mathrm{CcEOn}$ as a promising to control gastrointestinal infections in sheep. However further investigation with different doses and formulations are necessary to improve the efficacy and reduce toxicity.

\section{Acknowledgements}

This work received financial support from Conselho Nacional de Desenvolvimento Científico e Tecnológico (CNPq), Coordenação de Aperfeiçoamento de Pessoal de Nível Superior (CAPES) and Fundaçáo Cearense de Apoio ao Desenvolvimento Científico e Tecnológico (FUNCAP). Dr. Bevilaqua has a grant from CNPq.

\section{References}

Adams RP. Identification of essential oil components by gas chromatography/ quadrupole mass spectroscopy. 3rd ed. Illinois: Allured; 2001.

Ademola IO, Fagbemi BO, Idowu SO. Evaluation of the anthelmintic activity of Khaya senegalensis extract against gastrointestinal nematodes of sheep: in vitro and in vivo studies. Vet Parasitol 2004; 122(2): 151164. http://dx.doi.org/10.1016/j.vetpar.2004.04.001. PMid:15177720.

André WPP, Cavalcante GS, Ribeiro WLC, Santos JML, Macedo ITF, Paula HCB, et al. Anthelmintic effect of thymol and thymol acetate on sheep gastrointestinal nematodes and their toxicity in mice. Rev Bras Parasitol Vet 2017; 26(3): 323-330. http://dx.doi.org/10.1590/s198429612017056. PMid:28977246.

André WPP, Ribeiro WLC, Oliveira LMB, Macedo ITF, Rondon FCM, Bevilaqua CML. Óleos essenciais e seus compostos bioativos no controle de nematoides gastrintestinais de pequenos ruminantes. Acta Sci Vet 2018; 46: 1522. http://dx.doi.org/10.22456/1679-9216.81804.

Anthony JP, Fyfe L, Smith H. Plant active components - a resource for antiparasitic agents? Trends Parasitol 2005; 21(10): 462-468. http:// dx.doi.org/10.1016/j.pt.2005.08.004. PMid:16099722.

Bauske EM, Rodríguez-Kábana R, Estaún V, Kloepper JW, Robertson DG, Weaver CF, et al. Management of Meloidogyne incognita on cotton by use of botanical aromatic compounds. Nematropica 1994; 24(2): 143-150.

Cabaret J. Reliable phenotypic evaluations of anthelmintic resistance in herbivores: how and when should they be done? In: Quick W. Anthelmintics: clinical pharmacology, uses in veterinary medicine and efficacy. New York: Nova Science Publisher; 2014. p. 1-26.

Camurça-Vasconcelos ALF, Bevilaqua CML, Morais SM, Maciel MV, Costa CTC, Macedo ITF, et al. Anthelmintic activity of Lippia sidoides essential oil on sheep gastrointestinal nematodes. Vet Parasitol 2008; 154(1-2): 167-170. http://dx.doi.org/10.1016/j.vetpar.2008.02.023. PMid:18423877.

Choi IH, Kim J, Shin SC, Park IK. Nematicidal activity of monoterpenoids against the pine wood nematode (Bursaphelenchus xylophilus). Russ $J$ Nematol 2007; 15(1): 35-40. 
Coles GC, Bauer C, Borgsteede FHM, Geerts S, Klei TR, Taylor MA, et al. World Association for the Advancement of Veterinary Parasitology (W.A.A.V.P.) methods for the detection of anthelmintic resistance in nematodes of veterinary importance. Vet Parasitol 1992; 44(1-2): 35-44. http://dx.doi.org/10.1016/0304-4017(92)90141-U. PMid:1441190.

Dash KM, Hall K, Barger IA. The role of arithmetic and geometric mean worm egg counts in faecal egg count reduction tests and in monitoring strategic drenching programs in sheep. Aust Vet J 1988; 65(2): 66-68. http://dx.doi.org/10.1111/j.1751-0813.1988.tb07359.x. PMid:3355458.

Dash M, Chiellini F, Ottenbrite RM, Chiellini E. Chitosan - a versatile semi-synthetic polymer in biomedical applications. Prog Polym Sci 2011; 36(8): 981-1014. http://dx.doi.org/10.1016/j.progpolymsci.2011.02.001.

Fandohan P, Gnonlonfin B, Laleye A, Gbenou JD, Darboux R, Moudachirou M. Toxicity and gastric tolerance of essential oils from Cymbopogon citratus, Ocimum gratissimum and Ocimum basilicum in Wistar rats. Food Chem Toxicol 2008; 46(7): 2493-2497. http://dx.doi. org/10.1016/j.fct.2008.04.006. PMid:18511170.

Fortes FS, Molento MB. Resistência anti-helmíntica em nematoides gastrintestinais de pequenos ruminantes: avanços e limitaçóes para seu diagnóstico. Pesq Vet Bras 2013; 33(12): 1391-1402. http://dx.doi. org/10.1590/S0100-736X2013001200001.

Gonsalves JKMC, Costa AMB, Sousa DP, Cavalcanti SCH. Microencapsulação do óleo essencial de Citrus sinensis (L) Osbeck pelo método da coacervação simples. Scientia Plena 2009; 5(11): 1-8.

Hejazi R, Amiji M. Chitosan-based gastrointestinal delivery systems. J Control Release 2003; 89(2): 151-165. http://dx.doi.org/10.1016/S01683659(03)00126-3. PMid:12711440.

Hierro I, Valero A, Navarro MC. In vivo larvicidal activity of monoterpenic derivatives from aromatic plants against $\mathrm{L}_{3}$ larvae of Anisakis simplex s.l. Phytomedicine 2006; 13(7): 527-531. http://dx.doi.org/10.1016/j. phymed.2005.05.001. PMid:16785045.

Hubert J, Kerboeuf D. A microlarval development assay for the detection of anthelmintic resistance in sheep nematodes. Vet Rec 1992; 130(20): 442-446. http://dx.doi.org/10.1136/vr.130.20.442. PMid:1621342.

Kotze AC, Prichard RK. Anthelmintic resistance in Haemonchus contortus: history, mechanisms and diagnosis. Adv Parasitol 2016; 93: 397-428. http://dx.doi.org/10.1016/bs.apar.2016.02.012. PMid:27238009.

Macedo ITF, Bevilaqua CML, Oliveira LMB, Camurça-Vasconcelos ALF, Vieira LS, Amóra SSA. Evaluation of Eucalyptus citriodora essential oil on goat gastrointestinal nematodes. Rev Bras Parasitol Vet 2011; 20(3): 223-227. http://dx.doi.org/10.1590/S1984-29612011000300009. PMid:21961753.

Macedo ITF, Bevilaqua CML, Oliveira LMB, Camurça-Vasconcelos ALF, Vieira LS, Oliveira FR, et al. Anthelmintic effect of Eucalyptus staigeriana essential oil against goat gastrointestinal nematodes. Vet Parasitol 2010; 173(1-2): 93-98. http://dx.doi.org/10.1016/j.vetpar.2010.06.004. PMid:20609526.

Macedo ITF, Oliveira LMB, Ribeiro WLC, Santos JML, Silva KC, Filho JVA, et al. Anthelmintic activity of Cymbopogon citratus against Haemonchus contortus. Rev Bras Parasitol Vet 2015; 24(3): 268-275. http:// dx.doi.org/10.1590/S1984-29612015059. PMid:26444058.

Mesquita MA, Silva Júnior JB, Panassol AM, Oliveira EF, CamurçaVasconcelos ALF, Paula HCB, et al. Anthelmintic activity of Eucalyptus staigeriana encapsulated oil on sheep gastrointestinal nematodes. Parasitol Res 2013; 112(9): 3161-3165. http://dx.doi.org/10.1007/s00436-0133492-2. PMid:23783400.
Oka Y, Nacar S, Putievsky E, Ravid U, Zohara Y, Spiegel Y. Nematicidal activity of essential oils and their components against the root-knot nematode. Nematology 2000; 90(7): 710-715. http://dx.doi.org/10.1094/ PHYTO.2000.90.7.710. PMid:18944489.

Raut JS, Karuppayil SM. A status review on the medicinal properties of essential oils. Ind Crops Prod 2014; 62: 250-264. http://dx.doi. org/10.1016/j.indcrop.2014.05.055.

Ribeiro JC, Ribeiro WLC, Camurça-Vasconcelos ALF, Macedo ITF, Santos JML, Paula HCB, et al. Efficacy of free and nanoencapsulated Eucalyptus citriodora essential oils on sheep gastrointestinal nematodes and toxicity for mice. Vet Parasitol 2014; 204 (3-4): 243-248. http://dx.doi. org/10.1016/j.vetpar.2014.05.026. PMid:24929446.

Ribeiro WLC, Camurça-Vasconcelos ALF, Macedo ITF, Santos JML, Araújo-Filho JV, Ribeiro JC, et al. In vitro effects of Eucalyptus staigeriana nanoemulsion on Haemonchus contortus and toxicity in rodents. Vet Parasitol 2015; 212(3-4): 444-447. http://dx.doi.org/10.1016/j.vetpar.2015.07.019. PMid:26233731.

Ribeiro WLC, Macedo ITF, Santos JML, Oliveira EF, CamurçaVasconcelos ALF, Paula HCB, et al. Activity of chitosan-encapsulated Eucalyptus staigeriana essential oil on Haemonchus contortus. Exp Parasitol 2013; 135(1): 24-29. http://dx.doi.org/10.1016/j.exppara.2013.05.014. PMid:23748159.

Ritter RA, Monteiro MVB, Monteiro FOB, Rodrigues ST, Soares ML, Silva JCR, et al. Ethnoveterinary knowledge and practices at Colares island, Pará state, eastern Amazon, Brazil. J Ethnopharmacol 2012; 144(2): 346-352. http://dx.doi.org/10.1016/j.jep.2012.09.018. PMid:23000170.

Roberts FHS, O'Sullivan PJ. Methods for egg counts and larval cultures for strongyles infesting the gastrointestinal tract of cattle. Aust J Agric Res 1950; 1(1): 99-102. http://dx.doi.org/10.1071/AR9500099.

Roeber F, Morrison A, Casaert S, Smith L, Claerebout E, Skuce P. Multiplexed-tandem PCR for the specific diagnosis of gastrointestinal nematode infections in sheep: an European validation study. Parasit Vectors 2017; 10(1): 226. http://dx.doi.org/10.1186/s13071-017-2165-x. PMid:28482924.

Saddiq A, Khayyat S. Chemical and antimicrobial studies of monoterpene: citral. Pestic Biochem Physiol 2010; 98(1): 89-93. http://dx.doi.org/10.1016/j. pestbp.2010.05.004.

Sosnik A, Neves J, Sarmento B. Mucoadhesive polymers in the design of nano-drug delivery systems for administration by non-parenteral routes: a review. Prog Polym Sci 2014; 39(12): 2030-2075. http://dx.doi. org/10.1016/j.progpolymsci.2014.07.010.

Tiwari SK, Tzezana R, Zussman E, Venkatraman SS. Optimizing partition-controlled drug release from electrospun core-shell fibers. Int J Pharm 2010; 392(1-2): 209-217. http://dx.doi.org/10.1016/j. ijpharm.2010.03.021. PMid:20227472.

Ueno H, Gonçalves PC. Manual para diagnóstico das helmintoses de ruminantes. Tokyo: Japan International Cooperation Agency; 1998.

Wood IB, Amaral NK, Bairden K, Duncan JL, Kassai T, Malone JB $\mathrm{Jr}$, et al. World Association for the Advancement of Veterinary Parasitology (W.A.A.V.P.) second edition of guidelines for evaluating the efficacy of anthelmintics in ruminants (bovine, ovine, caprine). Vet Parasitol 1995; 58(3): 181-213. http://dx.doi.org/10.1016/0304-4017(95)00806-2. PMid:7571325.

Woranuch S, Yoksan R. Eugenol-loaded chitosan nanoparticles: I. Thermal stability improvement of eugenol through encapsulation. Carbohydr Polym 2013; 96(2): 578-585. http://dx.doi.org/10.1016/j.carbpol.2012.08.117. PMid:23768603. 